\title{
Plastic litter distribution in Pulau Rambut Wildlife Sanctuary
}

\author{
Regia Nadyanti Ivonie $^{1^{*}}$ and Ani Mardiastuti ${ }^{1}$ \\ ${ }^{1}$ Department of Conservation of Forest Resources and Ecotourism, Faculty of Forestry and \\ Environment, IPB University, Bogor, 16680, Indonesia
}

\begin{abstract}
It is not a secret that human activities caused marine litter. Marine litter has become a significant threat and pollutant problem globally, with plastic being the most predominant type of marine litter. It is reported that Pulau Rambut Wildlife Sanctuary, a home and an essential habitat of various species of waterbirds, has been facing marine litter, mostly plastic waste, as a significant threat. This paper aims to identify marine litter's occurrence and distribution, especially plastic, in Pulau Rambut Wildlife Sanctuary. Data was conducted using a modification of the shoreline survey method by National Oceanic and Atmospheric Administration (NOAA) and a visual survey. Sampling consisted of collecting a macro litter $(>2.5 \mathrm{~cm})$ from four plots representing each type of land cover in Pulau Rambut. Foam and plastic are two categories of litter that were commonly found on the island. Plastic spreads in the north to the east part of the island while styrofoam spreads in the west and northwest part of the island. Keywords. Marine litter, plastics, plastic pollution, Pulau Rambut, styrofoam.
\end{abstract}

\section{Introduction}

It is widely known that marine litter currently had become a significant threat and pollutant problem in the world. About $80 \%$ of it came from the land [1] that has been discharged into the ocean via the river [2]. Plastic is the most common type of marine litter, which also can be found in the remotest area. There are currently 150 million tons of plastics in the world's oceans, and it is also estimated that by 2050 , there will be more plastic than fish in the ocean [3]. It is also estimated that around 1.1 to 8.8 million metric tons of waste have entered the ocean because of the mismanagement of the waste [1]. This fact was corroborated by the history of marine litter research, which is closely connected to plastic use growth since plastic is an ideal material to use because of their low density, durability, excellent barrier properties, and relatively low cost to produce [4].

There are records of the problem affecting the biodiversity loss and habitat change caused by marine litter. The accumulation of marine litter in several ecosystems such as coral reefs, mangroves, and seagrass can also disrupt these ecosystems, harm the wildlife and marine life that depend on these ecosystems. Ingestion and entanglement are two

\footnotetext{
* Corresponding author: regianivonie@gmail.com
} 
common examples of how plastic affected the decline in wildlife. Around $90 \%$ of seabirds eat plastic annually [5] as they mistook it for their food.

Indonesia was identified as the second most plastic waste globally, with $10.1 \%$ of total mismanaged plastic waste and generated 0.48 to 1.29 million metric tons to the ocean per year [1]. Several studies on marine litter have been conducted in Indonesia, from a waste study in Pulau Seribu Archipelago in from 1997 [6] to the distribution of marine debris in Selayar Island, South Sulawesi in 2017 [7].

Pulau Rambut is a part of Pulau Seribu Archipelago located in the Jakarta Bay, where 13 rivers from Java ended up in the bay. As a result, some litter were intentionally or unintentionally dumped from Jakarta and drifted into Jakarta Bay [6]. There are 14 out of 15 species of waterbirds in Pulau Rambut Wildlife Sanctuary that depend on mangroves as their habitat [8]. It is reported that Pulau Rambut has been facing marine litter as significant problem. The accumulations of marine litter were found in nearly every part of Pulau Rambut, which can be very harmful since it is a home and essential habitat to various waterbird species. Therefore, a study about marine litter in Pulau Rambut Wildlife Sanctuary needs to be done to further management action. This paper aims to identify marine litter's occurrence and distribution most plastic in Pulau Rambut Wildlife Sanctuary.

\section{Method}

The study was located in Pulau Rambut Wildlife Sanctuary, a home and essential habitat of various species of waterbirds. Pulau Rambut has five types of land cover, such as beach, beach forest, secondary forest, secondary mangrove forest, and primary mangrove forest. Fig. 1 shows the location of the four plots that represent each type of land cover in Pulau Rambut Wildlife Sanctuary.

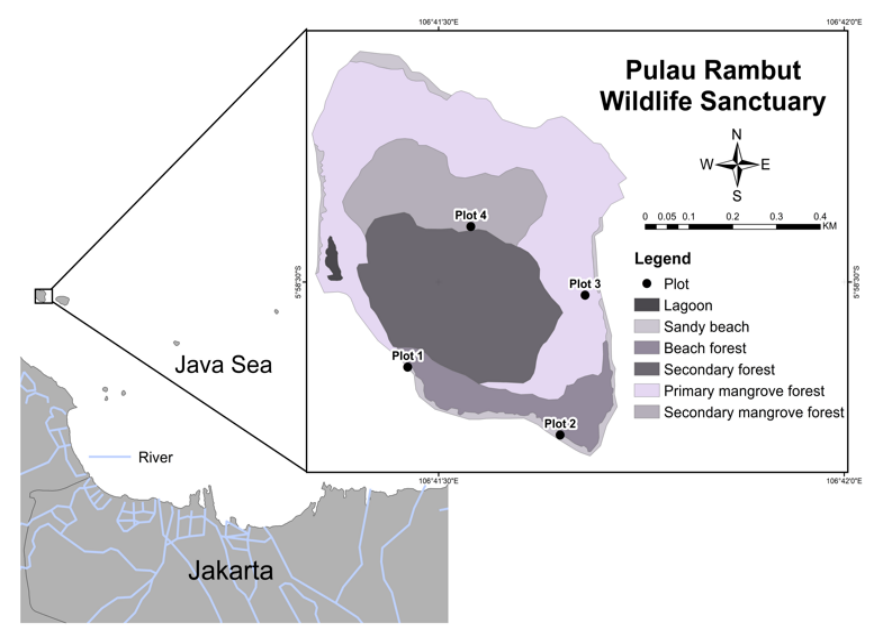

Fig. 1. Location of plots of this study (Ivonie, 2020).

Data of this study were collected using a modified version of the shoreline survey method by the National Oceanic and Atmospheric Administration (NOAA) [9] for beach and beach forest and a modified version of a visual survey for mangrove [10]. Sampling consisted of collecting a macro litter $(>2.5 \mathrm{~cm})$ from the plot [9]. The survey was conducted when the tide was at the lowest and repeated nine times within 19 days. Since this is an accumulative study, we removed the plot from all litter two days before. 


\section{Results and discussion}

\subsection{Marine litter}

The presence of marine litter in Pulau Rambut Wildlife Sanctuary has been recorded since 1992 with various of waste such as woods, bamboo, piece of cloths, paper wraps, rubbers, plastics, glass, cans, styrofoam, and synthetic leather which were found along the coast and within the mangrove [11]. Apart from synthetic leather, these types of litter were also found in this study. Usually, marine litter is classified into six categories: plastic, metal, glass, rubber, processed lumber/paper, and cloth/fabric [9]. However, marine litter that was found in this study were classified into two big categories: organic and non-organic. This classification is based on the ability of a material to decompose.

Organic litter consists of logs and bamboos. In contrast, there are seven sub-categories of non-organic litter, such as plastic, foam, metal, glass, rubber, fabric, and others. Although styrofoam is a part of a group of synthetic polymers like plastic, if styrofoam is in the same sub-category as plastic, the classification would be too generic since there is a lot amount of styrofoam that was found on the site [12]. From 98 types of marine litter found in Pulau Rambut, they are then classified into the seven sub-categories, as shown in Table 1.

Table 1. Non-organic types that were found in Pulau Rambut Wildlife Sanctuary.

\begin{tabular}{|c|c|}
\hline Categories & Types \\
\hline Plastic & $\begin{array}{c}\text { 6-pack rings, plastic cutlery, fishing lures, pens, pellets, HDPE bottle, } \\
\text { beverages bottle, sachet packaging, cigarette packs, saving box, funnel, } \\
\text { deodorant bottle, buckets, gallon bottle, plastic cups, hanger, hairpin, jerrycan, } \\
\text { cable, and earphones, plastic bags (film), membership card, plastic sacks, } \\
\text { cosmetic packages, medical packaging, plastic containers, cigarette lighters, } \\
\text { plastic milk box, motorcycle lights, fisher lamps, plastic toys, pacifier, } \\
\text { parachute, plastic film, sanitary napkins, puppets, mica plastic, medical bags, } \\
\text { diapers, flower pots, rigid plastic, bottle pumps, cigarette butts, band-aid } \\
\text { dispenser, armrest, gloves, plastic straws, hose, toothbrush, combs, stamps, } \\
\text { small tubes, plastic ropes, strapping, paint holder, soap dispenser, tarpaulin, } \\
\text { trash bags, tubes, bottle and container caps, and toothbrush cover }\end{array}$ \\
\hline Foam & Foam, fruit wrapper, plastic foam, styrofoam, and styrofoam fragments \\
\hline Metal & Tin cans, small tin box, beverage cans, and aerosol cans \\
\hline Glass & Lightbulbs, beverages bottles, deodorant bottles, and glass fragments \\
\hline Rubber & Footwears, fishing equipments, tires, rubber fragments, gloves, and bags \\
\hline Fabrics & $\begin{array}{c}\text { Footwears, wallets, belts, luggage tags, cloth masks, clothing, fabric pieces, } \\
\text { gloves, sofa, beds, pillows, dolls, ropes pieces, safety ropes, ropes, bags, and } \\
\text { headcovers }\end{array}$ \\
\hline Others & Car perfumes, air fresheners, electrical circuits, wet wipes, ceramic, and sink \\
\hline
\end{tabular}

\subsection{Type of plastic litter}

Decades ago, most of the existing waste consisted of a degradable material. Currently, existing waste often contains synthetic material like plastic [13]. About $95 \%$ of marine litter accumulated on the shoreline, the sea surface, and the seafloor were dominated by plastic [14]. This statement is consistent with data in the field. The vast majority of non-organic types were plastic (60 types) then followed by fabrics (14 types), and rubber (6 types). However, based on the accumulation per sub-category, foam, and plastic were the most abundant items found in Pulau Rambut (Fig. 2). 


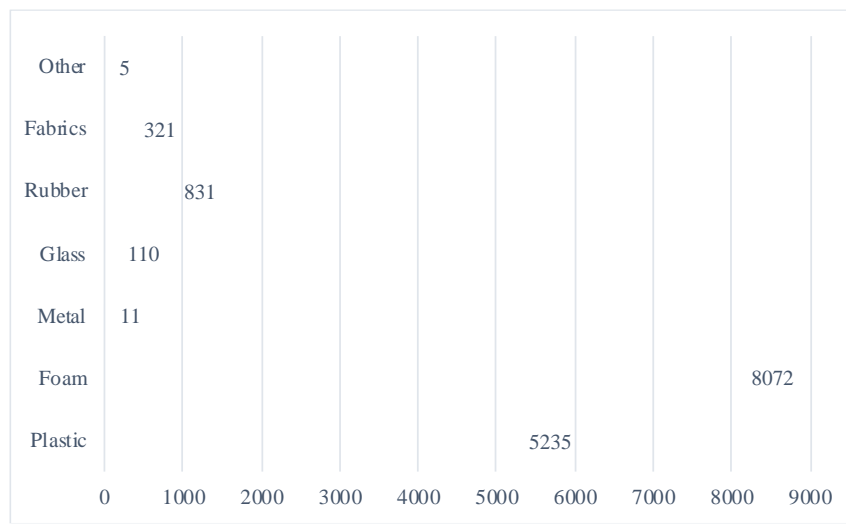

Fig. 2. The accumulation of non-organic litter.

Plastic and foam were significantly higher than other non-organic sub-categories. There were 60 types of plastic and five types of styrofoam that can be found on the island. A total of 5235 items of plastic and 8072 items from foam were found. However, only 11 types of plastic and three types of foam were over 100 items, as shown in Fig. 3.

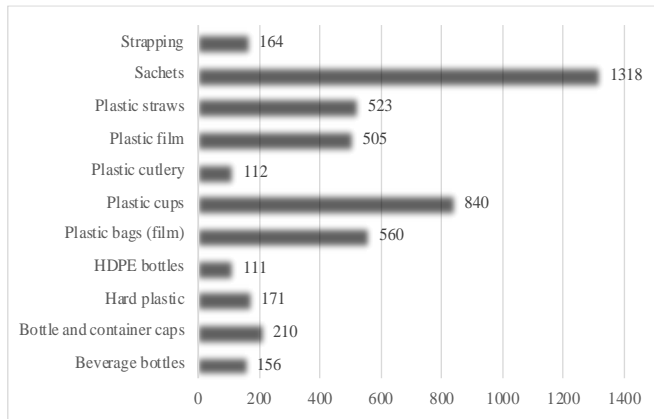

(a)

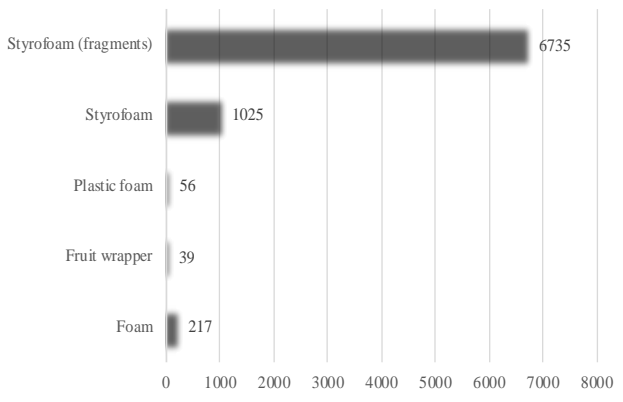

(b)

Fig. 3. The accumulation of (a) plastic and (b) foam.

Among plastic, sachets were the most commonly found. Sachet that was found usually came from a local product of instant drink and coffee. The second one is plastic cups. These plastic cups came from packaged drinking water and beverages cup from coffee shops. And the third is a plastic bag (film). In Indonesia, it is common to use plastic bags as a shopping bag; thus, the amount of plastic bags found is 560 items. Although some areas in Indonesia already banned plastic bags, it is still widely used by some other regions.

Styrofoam is an expanded polystyrene foam or known as white foam plastic materials [15]. Fragments styrofoam were the most frequently found in Pulau Rambut Wildlife Sanctuary. The size of the fragments was small but over 2.5 (Fig. 4). It made it barely possible to identify these fragments due to the deterioration of the original form. Hence the significant number of fragments of styrofoam that were found. 


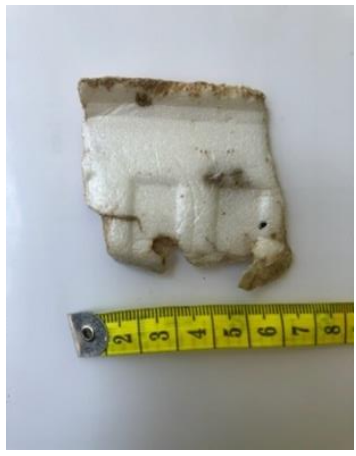

(a)

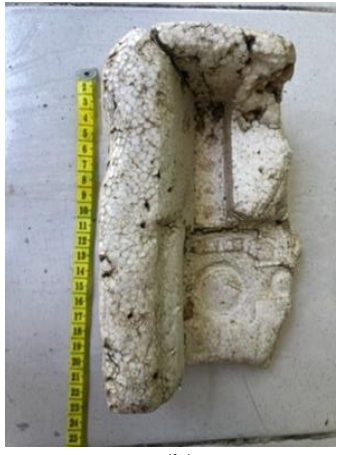

(b)

Fig. 4. The size of (a) fragment styrofoam and (b) styrofoam.

This finding shows that plastic and styrofoam have been a massive part of the human lifestyle. Undoubtedly most human activities are involved in using plastic since most of the product packaging has plastic material. Since plastic is one of the materials that are suitable for manufacture a wide variety of products [16] from product packaging, bottles, and cups, to part of vehicles. But the durability of plastic makes it hard to degrade naturally so that they will persist in the environment for many decades [17].

\subsection{Distribution of plastic litter}

From the previous study, most marine litters were found in the north area. Decades later, these litter not only were found in the north area, but it has extensively spread and stranded even in the remotest area of Pulau Rambut, as it is shown in Fig. 5.

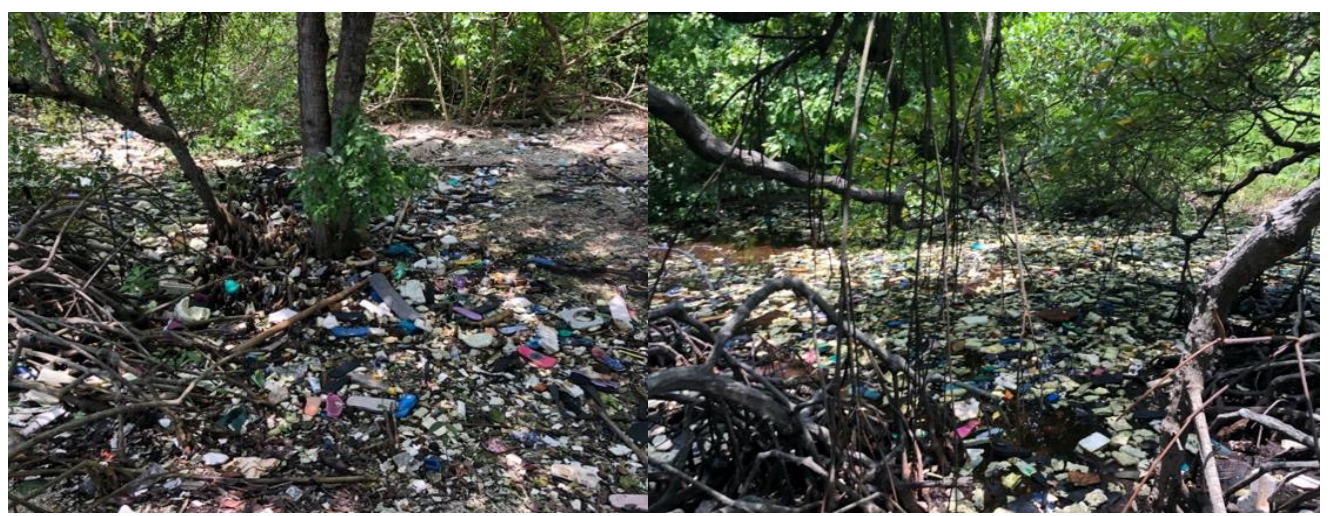

(a)

(b)

Fig. 5. Marine litter was found the island's remotest area: (a) in the border of secondary forest and secondary mangrove forest and (b) in the west part of the island near the lagoon.

The distribution of marine litter is affected by ocean current and wind streamlines. Based on the ocean current around Pulau Rambut in January 2020 was around 2.71 to 4.54 $\mathrm{m} / \mathrm{s}-1$ with the wind direction towards the southeast. Which explains the distribution of litter as it is shown in Fig. 6. The marine litter distribution was clustered into four (plastic, styrofoam, rubber, and logs and bamboos). These clusters were based on the dominating type that was found. 


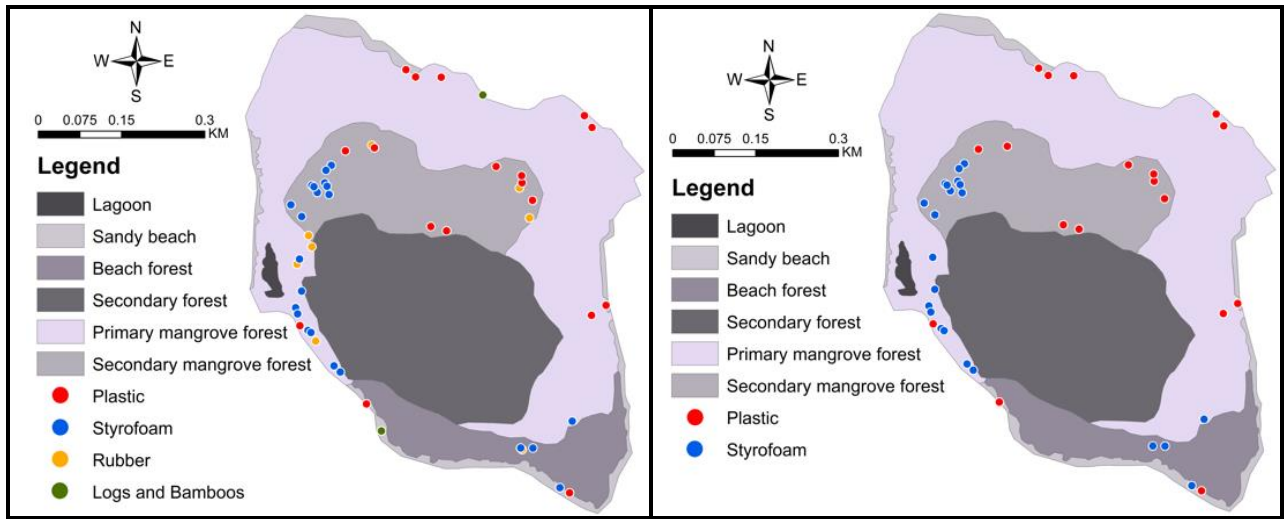

(a)

Fig. 6. The distribution of (a) litter and (b) plastic and styrofoam in Pulau Rambut Wildlife Sanctuary.

Styrofoam spreads in the west and northwest part of the island, whereas plastic spreads in the north to the east part of the island - the size of styrofoam and plastic and mangrove density determinate this distribution. The distribution of styrofoam can be found near the ocean, while plastic mostly infiltrated into the island's middle. A cluster of styrofoam tends to have a larger size than plastic, as shown in Fig. 7. Whereas plastic mostly consists of smaller objects like sachet and cups. Plastic is also floating, which increases the chance of plastic to spread [18]. The bigger the size of an object, the harder it gets to infiltrate the mangrove.

This litter was trapped in the prop roots of beach sediments. Accumulated marine litter in the mangrove ecosystem can prevent tides, increasing salinity levels, which will affect the ecosystem [19]. It also can disrupt the natural growth of mangroves and affect habitat change [20]. The change of habitat will be likely to affect waterbird species that depend on Pulau Rambut Wildlife Sanctuary. It is also reported that marine litter can be found in prop roots or beach sediment, but one species of waterbirds called little black cormorant (Phalacrocorax sulcirostris) in Pulau Rambut Wildlife Sanctuary, used synthetic ropes as a material of their nest [21].

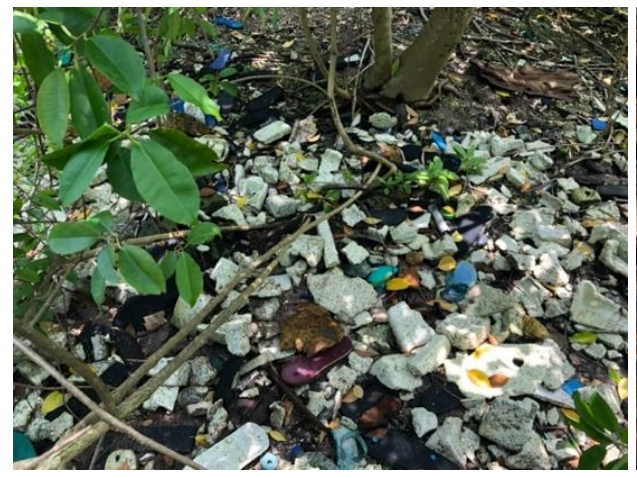

(a)

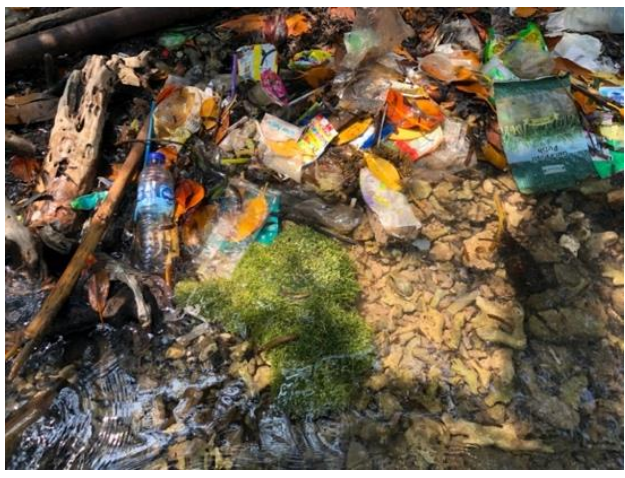

(b)

Fig. 7. The size of (a) styrofoam and (b) plastic that was trapped on the island.

The distance between Pulau Rambut and the nearest mainland also affects the distribution of litter. Most probably, these litters came from the nearest mainland to Pulau Rambut. The nearest mainland to Pulau Rambut is Java Island specifically the province of Jakarta and Tanjung Pasir (Tanggerang). In Jakarta, it is reported that approximately 41 
tons $(25 \%)$ of 165 tons of waste which are extracted daily from Jakarta's main waterways, are plastics [3]. Most of the marine litter comes from land-based activities and most likely because of the waste mismanagement. But it can't be concluded the sources of this litter came from. Therefore, further research about marine and plastic litter sources needs to be done to know for sure the litter sources.

\section{Conclusion}

Marine litter in Pulau Rambut Wildlife Sanctuary is classified into two categories, organic and non-organic. Organic litter consists of logs and bamboos. Simultaneously, non-organic litter has seven sub-categories such as plastic, foam, metal, glass, rubber, fabrics, and others. Foam and plastic are two categories of litter that was commonly found on the island. It shows that plastic and styrofoam have been an enormous part of the human lifestyle. Plastic spreads in the north to the east part of the island while styrofoam spreads in the west and northwest part of the island. The distribution is affected by the ocean current, and wind also streamlines the size of an object, the density of the mangrove, and the distance between the island and nearest mainland.

\section{Acknowledgements}

This research is funded by Ministry of Research and Technology/National Research and Innovation Agency of Republic Indonesia through Competitive National Master Thesis Research with contract number 1/AMD/E1.KP.PTNBH/2020. Thanks to Dede Aulia Rahman as one of the supervisor of this research

\section{References}

1. J.R. Jambeck, R. Geyer, C. Wilcox, T.R. Siegler, M. Perryman, A. Andrady, R. Narayan, K.L. Law, Plastic waste inputs from land into the ocean, Science. 347, 768 (2015) https://doi.org/10.1126/science.1260352

2. C. Schmidt, T. Krauth, S. Wagner, Export of plastic debris by rivers into the sea. Environ. Sci. Technol. 51, 12246 (2017) https://doi.org/10.1021/acs.est.7b02368

3. World Bank. Indonesia Marine Debris Hotspot: Rapid Assessment Synthesis Report. (World Bank, Washington DC, 2018)

4. P.G. Ryan, A brief history of marine litter research, In: M. Bergmann, L. Gutow, M. Klages, Marine Anthropogenic Litter. (Springer, New York, 2015)

5. C. Wilcox, E. Van Sebille, B.D. Hardesty, Threat of plastic pollution to seabirds is global, pervasive, and increasing, Proc. Natl. Acad. Sci. USA. 112, 11899 (2015) https:doi.org/10.1073/pnas.1502108112

6. P.A. Uneputty, S.M. Evans, Accumulation of beach litter on islands of the Pulau Seribu Archipelago, Indonesia. Mar. Pollut. Bull. 34, 652 (1997) https://doi.org/10.1016/S0025-326X(97)00006-4

7. R. Hermawan, A. Damar, S. Hariyadi, Daily accumulation and impacts of marine litter on the shores of Selayar Island Coast, South Sulawesi. Waste Technol. 5, 6 (2017) http://dx.doi.org/10.12777/wastech.5.1.15-20

8. A. Mardiastuti, Ecology of Avian Community of Pulau Rambut: Population, Nest Site Distribution, and Foraging Sites. (IPB Press, Bogor, 2001)

9. S. Lippiatt, S. Opfer, C. Arthur, Marine Debris Monitoring and Assessment. (NOAA Marine Debris Program, Maryland, 2013) 
10. C. Martin, H. Almahasheer, C.M. Duarte, Mangrove forests as traps for marine litter. Environ Pollut. 247, 499 (2019) https://doi.org/10.1016/j.envpol.2019.01.067

11. A. Mardiastuti, Habitat and Nest-site Characteristics of Waterbirds in Pulau Rambut Nature Reserve, Jakarta Bay, Indonesia. (Michigan State University, Michigan, 1992)

12. R.N. Ivonie, A. Mardiastuti, D.A. Rahman, Proposed classification of waste that landed on small island in Indonesia for the conservation of waterbirds. IOP Conf. Ser.: Earth Environ. Sci. 528, 012012 (2020) https://doi.org/10.1088/1755$1315 / 528 / 1 / 012012$

13. L. Van Cauwenberghe, M. Claessens, M.B. Vandegehuchte, J. Mees, C.R. Janssen, Assessment of marine debris on the Belgian Continental Shelf. Mar. Pollut. Bull. 73, 161 (2013) http://doi.org/10.1016/j.marpolbul.2013.05.026

14. F. Galgani, G. Hanke, T. Maes, Global distribution, composition, and abundance of marine litter, In: M. Bergmann, L. Gutow, M. Klages, Marine Anthropogenic Litter. (Springer, New York, 2015)

15. Omnexus, Omnexus (2019) https://omnexus.specialchem.com/selectionguide/expanded-polystyrene-eps-foam-insulation

16. J.G.B. Derraik, The pollution of the marine environment by plastic debris: a review. Mar. Pollut. Bull. 44, 842 (2002) https://doi.org/10.1016/S0025-326X(02)00220-5

17. P.G. Ryan, C.J. Moore, J.A. van Franeker, C.L. Moloney, Monitoring the abundance of plastic debris in the marine environment, Phil. Trans. R. Soc. B. 364, 1999 (2009) https://doi.org/10.1098/rstb.2008.0207

18. M. Vikas, G.S. Swarakish, Coastal Pollution: A Review, Aquat. Procedia. 4, 381 (2015) https://doi.org/10.1016/ j.aqpro.2015.02.051

19. NOAA, Habitat: Marine Debris Impact on Coastal and Benthic Habitats. (NOAA, Maryland, 2016)

20. A.O. Debrot, J. van Rijn, P. S. Bron, R. de León, A baseline assessment of beach debris and tar contamination in Bonaire, Southeastern Caribbean, Mar. Pollut. Bull. 71, 325 (2013) http://doi.org/10.1016/j.marpolbul.2013.01.027

21. A. Fithri, Analisa Bahan Sarang Burung Pecuk Padi Hitam (Phalacrocorax sulcirostris) di Suaka Margasatwa Pulau Rambut, Teluk Jakarta, Berita Biologi. 8, 241 (2007) 